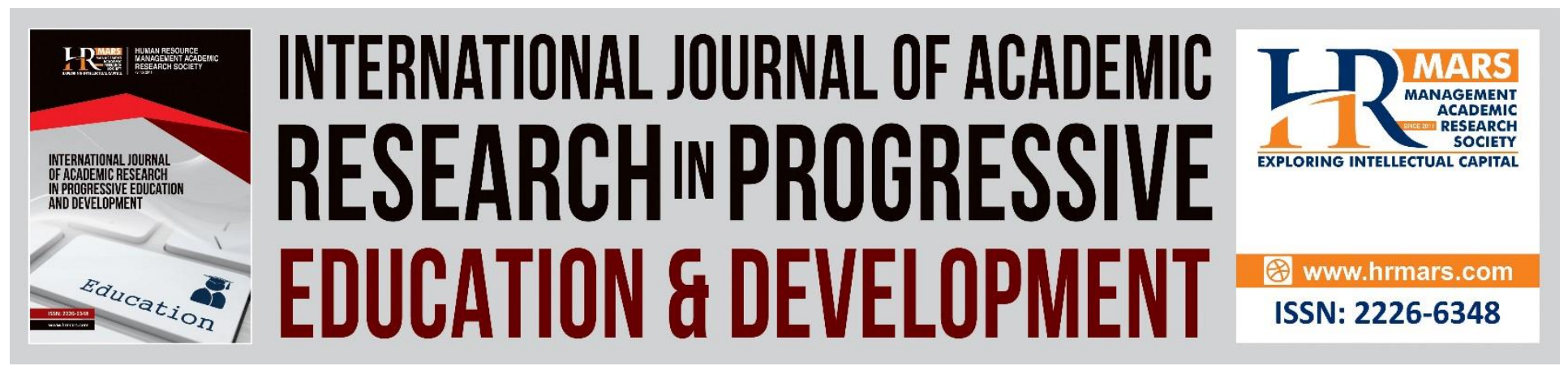

\title{
Embedding Information and Communication Technology in Reading Skills Instruction: Do Slow Learners Special Needs Ready for it?
}

\section{Noor Aini Ahmad}

To Link this Article: http://dx.doi.org/10.6007/IJARPED/v7-i3/4576

DOI: $10.6007 /$ IJARPED/v7-i3/4576

Received: 25 May 2018, Revised: 27 June 2018, Accepted: 13 July 2018

Published Online: 24 July 2018

In-Text Citation: (Ahmad, 2018)

To Cite this Article: Ahmad, N. A. (2018). Embedding Information and Communication Technology in Reading Skills Instruction: Do Slow Learners Special Needs Ready for it? International Journal of Academic Research in Progressive Education and Development, 7(3), 582-591.

\section{Copyright: (C) 2018 The Author(s)}

Published by Human Resource Management Academic Research Society (www.hrmars.com)

This article is published under the Creative Commons Attribution (CC BY 4.0) license. Anyone may reproduce, distribute, translate and create derivative works of this article (for both commercial and non-commercial purposes), subject to full attribution to the original publication and authors. The full terms of this license may be seen at: http://creativecommons.org/licences/by/4.0/legalcode

Vol. 7, No. 3, July 2018, Pg. 582 - 591

Full Terms \& Conditions of access and use can be found at http://hrmars.com/index.php/pages/detail/publication-ethics 


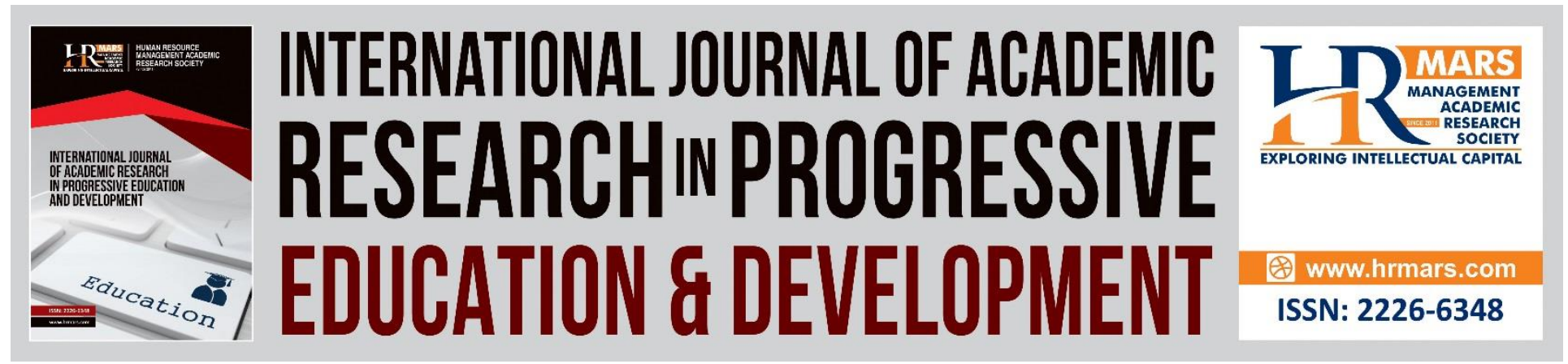

\title{
Embedding information and communication technology in reading skills instruction: Do slow learners special needs ready for it?
}

\author{
Noor Aini Ahmad \\ Special Education Department, Faculty of Human Development \\ Universiti Pendidikan Sultan Idris
}

\begin{abstract}
Current literature suggests a lack of empirically validated tecqnique in teaching reading skills especially among slow learners. The current study implemented a single subject design to investigate the effect of direct instruction in single-word reading on the performance of students with special needs who use augmented reality materials. Findings revealed that after using the LitAR module during the treatment sessions, the scores increased for the slow learners (95.0) and this shows that slow learners are prominent to the treatment after undergoing the treatment session using the LitAR module. Results provide evidence of augmented reality application for slow learner students is an effective solution to improve reading skills performance.

Keywords: Reading Skills, Slow Learners, Augmented Reality
\end{abstract}

\section{Introduction}

According to Lo, Wang \& Yeh (2004), teachers should give more attention to individual differences when teaching and providing remedial instruction. However, Lin, Liu, Chen, Liou, Chang, Wu \& Yuan (2013) notice that only few studies discussed students' learning performance in remedial instruction context.

Beginner readers usually concentrate on decoding words. At this point, the content of the text or the word should be familiar so that once a word is decoded; students know the meaning of the word (Patton, Crosby, Houchins \& Jolivette, 2010). Their opportunities for academic success are dependent on having well prepared teachers who understand the strengths and limitations the students bring to the classroom (Paneque \& Rodriguez, 2009). Literacy helps children to think in a more sophisticated ways (Temple, Ogle, Crawford \& Freppon, 2005). Most of the time, reading comprehension is a crucial skill for academic success of all students (Stetter \& Hughes, 2011). It will cause readers to read slowly and will impact their understanding and 
INTERNATIONAL JOURNAL OF ACADEMIC RESEARCH IN PROGRESSIVE EDUCATION AND DEVELOPMENT

Vol. 7, No. 3, July 2018, E-ISSN: 2226-6348 @ 2018 HRMARS

reading performances (Rasinski, 2006). At the earliest stages of reading, almost all words are unknown.

\section{Background}

Literacy development of special education students is a topic that has been at the center of debates revolved around school reforms (Orelus \& Hills, 2010). Most research examining this issue consists of controlled studies of specific treatments, conducted within a single school or district, with children who reside in the district, and outcomes are assessed after a relatively a short period of time (Vandenberg \& Emery, 2009). Special education placement is associated with stigma and poor educational outcomes (Faye, 2013). But eventually, too many incorrect referrals were made and many students who needed help were never placed in special education and therefore never helped (White, Polly \& Audette, 2012).

Many study has contributed to scientific knowledge about the development of intelligence and shown that the teaching process is one of the most effective methods to increase academic learning (Pérez \& Beltrán, 2008). Teachers, psychologists and social workers working with children and parents might consider the wider use of video modelling as reinforcement when teaching a range of skills particularly where traditional teaching methods have proved to be ineffective (Mohammed Alzyoudi, Abed Alziz Sartawi \& Osha Almuhiri, 2014). Few studies reported standardized measures of reading comprehension with majority of study treatments utilized strategy instruction related to main idea or summarization (Solis, Ciullo, Vaughn, Pyle, Hassaram \& Leroux, 2012). Hence, teachers need to have more knowledge in information and communication technology (ICT) and one of the way is by using augmented reality in education.

\section{Problem Statement}

Students with reading difficulties benefit from instruction that is purposeful and targeted at important objectives that students need to learn, progressing logically from easier to more challenging skills (Denton, 2012). Learning disability is defined and a line is drawn between learning disabilities and school difficulties resulting from other causes such as inadequate school management and lack of well-trained and effective teachers in the schools (Abosi, 2007). Thus, embedding information and communication technology in reading skills instruction is considered an educational priority.

Multimedia-based systems have become widely available but many systems, however, provide little interactivity to learners (Zhang, 2003). The instructional materials can be delivered in a multi-sensory environment using the multimedia elements such as text, graphics, animation, sound and video (Tse-Kian Neo \& Mai Neo, 2004). Multimedia is clearly an educational resource with astonishing potential, but to be effective the tools must be carefully implemented (Schulz \& Dahale, 1999). Media should be applied or used in the context of the material being learned and the individual learner (Jandi, 2000).

Thus, this study tries to investigate if augmented reality could be a great help in teaching

reading skills to slow learners. Specifically, the following research questions were investigated if 
INTERNATIONAL JOURNAL OF ACADEMIC RESEARCH IN PROGRESSIVE EDUCATION AND DEVELOPMENT

Vol. 7, No. 3, July 2018, E-ISSN: 2226-6348 @ 2018 HRMARS

the augmented reality technique able to improve single-word reading performance among slow learners.

\section{Literature review Slow Learners}

High flyers, average learners and slow-learners were all exposed to the educational tool and all showed enhanced self-confidence, increasing levels of spoken communication, cooperation, shared leadership role more frequently and developed a positive attitude towards learning as compared to pupils taught using traditional methods (Bahadur \& Boodun, 2013). Multimedia software and multimedia learning environments have been proven to be effective in helping children with disabilities to develop literacy and numeracy skills, living skills and social interaction (Lee Lay Wah, 2007). Thus, early interventions and ICT will give opportunities to slow learner students to be a better reader.

\section{Interactive Multimedia}

In addition, interactive multimedia activity can effectively assist in the acquisition of literacy, numeracy and life skills in the foundation phase and provide a valuable resource for language learning and teaching at both primary and secondary levels of schooling (Norhayati \& Siew Pei Hwa, 2015). Mayer (2003) strongly claimed that the use of multimedia is an effective teaching and learning tool because it helps educator in promoting student understanding.

Reading, comprised such elements as orthographic and syntactic knowledge as well as the formation of propositions and inferences, requires several cognitive and informationprocessing skills (Shamir, Korat \& Barbi, 2008). E-books usually include multimedia effects such as oral reading, written text, oral discourse, music, sound effects and animations (Korat, 2010). Interactive storybook reading helps children expand their vocabulary and gain insight into the structure of narrative text (Seagers \& Verhoeven, 2002). The importance of information and communication technology in teaching and learning cannot be denied since it has been used effectively to help at-risk children to achieve their learning outcomes in language skills (Hargittai \& Shafer, 2006). Students with severe physical disabilities can participate actively in their fieldwork through assistive technologies (Nkansah \& Unwin, 2010). Thus, augmented reality presents a unique opportunity for slow learners to explore the potentiality that may be needed in reading skills.

\section{Method}

\section{Participants}

Student participants comprised of slow learner students who showed the characteristics for not mastering reading and writing skills. To ensure that only students who met the criteria were selected in this study, which focusing on the CVCV, CVCVCV, CVC and CVCVC words, teachers nominated them according to their latest performance in class. Students with marks more than $90 \%$ are eliminated from the study. 
Table 1: Experimental Groups

\begin{tabular}{lcc}
\hline Categories & Control Group & Treatment Group \\
\hline Slow learners & 8 & 8 \\
& & \\
\hline
\end{tabular}

Table 1 shows the experimental groups in the study. There were 16 students and were divided into two groups, the treatment groups $(n=8)$ and the control groups $(n=8)$. All participant show no other physical or neurological impairments and they attended either the first, second or the third year of public schools, in regular classrooms. All children were low in socio-economic status.

\section{Settings}

The study was conducted according to the terms laid out in the approval by the Ministry of Education. All treatment sessions were carried out within one to two hour duration for each categories and were conducted four days per week in a room allocated by the management at each school. Both schools were in the same district and one of the school is in rural area while the other is in sub rural area. These criteria will enrich the data collection because researchers are able to look into the usage of the module in both settings.

\section{Materials}

Materials included a module that consist of three elements, namely the Teachers Guideline Book, Activity Book and 55 cards. Each piece contain a printed word with illustration. 15 cards for the CVCV word group, 15 CVCVCV words, 12 CVC words and 13 CVCVC words. The module is part of Program Sokongan dan Bimbingan (Support and Guidance Program's) materials with its tagline Belajar Literasi Menggunakan Augmented Reality (Learn Literacy Using Augmented Reality) or better known as The LitAR. A pre-test were given to both group and only participants in the treatment groups will be assist with the module.

\section{Design and Procedures}

The procedure encompassed three general phases (1) pre-tests, (2) treatment and (3) post-test. The LitAR pre-tests involved asking participants to read and handwrite four Bahasa Malaysia group words components that contained simple syllables (consonant vowel syllables) and words. The LitAR module was design together with 55 cards of two or three syllables in Bahasa Malaysia group words. Each activities in the module establishes conditional relations between dictated words and printed words, dictated syllables and printed syllables and dictated words and syllables.

During the treatment, remedy activities using the LitAR module was apply to teach reading skills. The post-test was not given at the end of the three months period because according to Sella et al. (2016), target participants especially students with learning disabilities had short-term memory disorder. 
INTERNATIONAL JOURNAL OF ACADEMIC RESEARCH IN PROGRESSIVE EDUCATION AND

DEVELOPMENT

Vol. 7, No. 3, July 2018, E-ISSN: 2226-6348 @ 2018 HRMARS

\section{Results}

Table 3: Demographic Information of Slow Learners

\begin{tabular}{cccccccccc}
\hline \multicolumn{4}{c}{ Control Group } & \multicolumn{6}{c}{ Treatment Group } \\
No & CODE & $\begin{array}{c}\text { Gende } \\
\text {. }\end{array}$ & Etnic & Age & No. & CODE & $\begin{array}{c}\text { Gende } \\
\text { r Etnic }\end{array}$ & Age \\
\hline 1 & SL/CG/T/1 & M & Malay & 8 & 1 & SL/TG/1 & M & Malay & 8 \\
2 & $\mathrm{SL} / \mathrm{CG} / \mathrm{T} / 2$ & $\mathrm{M}$ & Malay & 8 & 2 & $\mathrm{SL} / \mathrm{TG} / 2$ & $\mathrm{M}$ & Malay & 8 \\
3 & $\mathrm{SL} / \mathrm{CG} / \mathrm{T} / 3$ & $\mathrm{~F}$ & Malay & 9 & 3 & $\mathrm{SL} / \mathrm{TG} / 3$ & $\mathrm{M}$ & Malay & 8 \\
4 & $\mathrm{SL} / \mathrm{CG} / \mathrm{T} / 4$ & $\mathrm{~F}$ & Malay & 9 & 4 & $\mathrm{SL} / \mathrm{TG} / 4$ & $\mathrm{M}$ & Malay & 8 \\
5 & $\mathrm{SL} / \mathrm{CG} / \mathrm{T} / 5$ & $\mathrm{~F}$ & Malay & 9 & 5 & $\mathrm{SL} / \mathrm{TG} / 5$ & $\mathrm{M}$ & Malay & 8 \\
6 & $\mathrm{SL} / \mathrm{CG} / \mathrm{T} / 6$ & $\mathrm{~F}$ & Malay & 9 & 6 & $\mathrm{SL} / \mathrm{TG} / 6$ & $\mathrm{M}$ & Malay & 8 \\
7 & $\mathrm{SL} / \mathrm{CG} / \mathrm{T} / 7$ & $\mathrm{M}$ & Malay & 9 & 7 & $\mathrm{SL} / \mathrm{TG} / 7$ & $\mathrm{M}$ & Malay & 8 \\
8 & $\mathrm{SL} / \mathrm{CG} / \mathrm{T} / 8$ & $\mathrm{M}$ & Malay & 9 & 8 & $\mathrm{SL} / \mathrm{TG} / 8$ & $\mathrm{~F}$ & Malay & 9 \\
\hline
\end{tabular}

Table 3 shows the demographic of slow learner participants of two selected schools. There were eight participants in the control group and eight participants in the treatment group. All participants are Malays with 11 male students and five female students. All the students were in Level One Primary School during the collecting data duration with range eight to nine years old and they were selected by the schools teachers based on their latest test achievements.

Table 4: Descriptive Statistic on Pre-test and Post-test Scored by Slow Learners

\begin{tabular}{|c|c|c|c|c|c|c|c|}
\hline \multirow[t]{2}{*}{ No. } & \multirow[t]{2}{*}{ Code } & \multicolumn{2}{|c|}{ Control Group } & \multirow[t]{2}{*}{ No. } & \multirow[t]{2}{*}{ Code } & \multicolumn{2}{|c|}{ Treatment group } \\
\hline & & Pre-test & $\begin{array}{c}\text { Post- } \\
\text { test }\end{array}$ & & & $\begin{array}{l}\text { Pre- } \\
\text { test }\end{array}$ & $\begin{array}{c}\text { Post- } \\
\text { test }\end{array}$ \\
\hline 1 & $\mathrm{SL} / \mathrm{CG} / \mathrm{T} / 1$ & 72 & 78 & 1 & $\mathrm{SL} / \mathrm{TG} / 1$ & 32 & 74 \\
\hline 2 & $\mathrm{SL} / \mathrm{CG} / \mathrm{T} / 2$ & 76 & 78 & 2 & $\mathrm{SL} / \mathrm{TG} / 2$ & 50 & 100 \\
\hline 3 & $\mathrm{SL} / \mathrm{CG} / \mathrm{T} / 3$ & 76 & 80 & 3 & $\mathrm{SL} / \mathrm{TG} / 3$ & 48 & 86 \\
\hline 4 & $\mathrm{SL} / \mathrm{CG} / \mathrm{T} / 4$ & 72 & 74 & 4 & $\mathrm{SL} / \mathrm{TG} / 4$ & 56 & 100 \\
\hline 5 & $\mathrm{SL} / \mathrm{CG} / \mathrm{T} / 5$ & 80 & 86 & 5 & $\mathrm{SL} / \mathrm{TG} / 5$ & 68 & 100 \\
\hline 6 & $\mathrm{SL} / \mathrm{CG} / \mathrm{T} / 6$ & 30 & 20 & 6 & SL/TG/6 & 56 & 100 \\
\hline 7 & $\mathrm{SL} / \mathrm{CG} / \mathrm{T} / 7$ & 16 & 16 & 7 & $\mathrm{SL} / \mathrm{TG} / 7$ & 54 & 100 \\
\hline 8 & $\mathrm{SL} / \mathrm{CG} / \mathrm{T} / 8$ & 12 & 18 & 8 & $\mathrm{SL} / \mathrm{TG} / 8$ & 54 & 100 \\
\hline \multicolumn{2}{|c|}{ Mean } & 54.2 & 56.2 & \multicolumn{2}{|c|}{ Mean } & 52.2 & 95.0 \\
\hline \multicolumn{2}{|c|}{ Mean Difference } & \multicolumn{2}{|c|}{2} & \multicolumn{2}{|c|}{ Mean Difference } & \multicolumn{2}{|c|}{42.8} \\
\hline
\end{tabular}


INTERNATIONAL JOURNAL OF ACADEMIC RESEARCH IN PROGRESSIVE EDUCATION AND DEVELOPMENT

Vol. 7, No. 3, July 2018, E-ISSN: 2226-6348 @ 2018 HRMARS

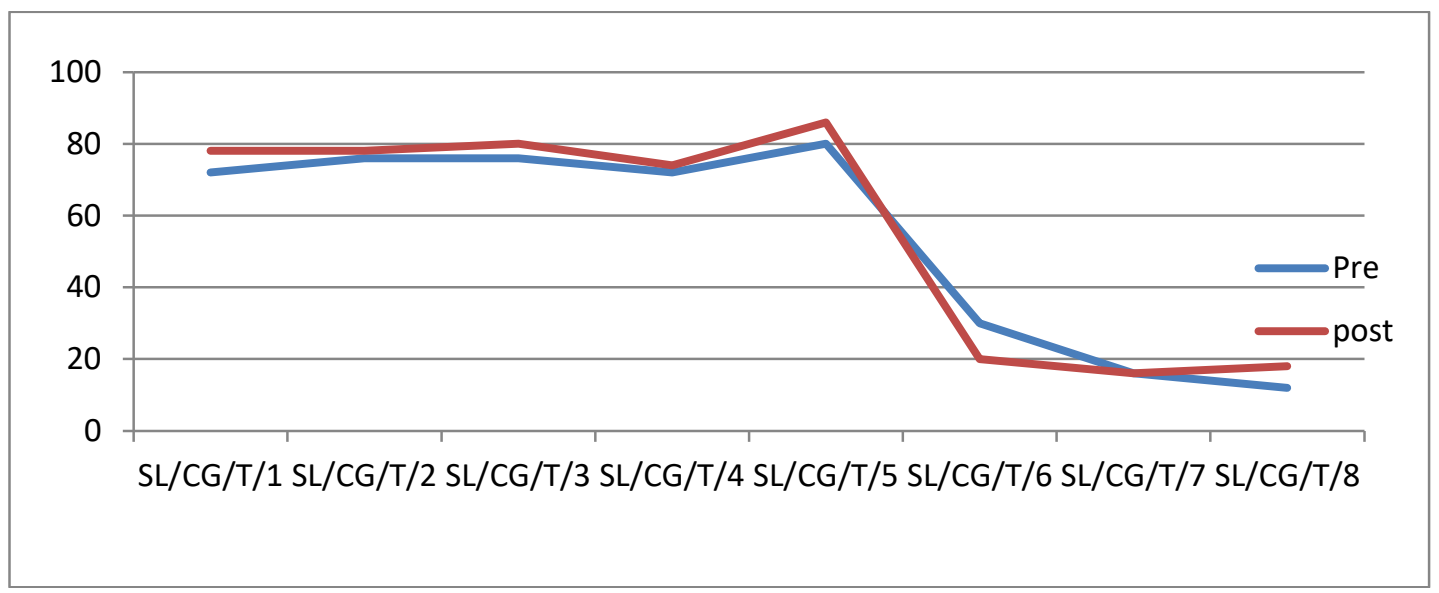

Graph 1: Pre-test and Post-test Scores for Slow Learners in Control Group

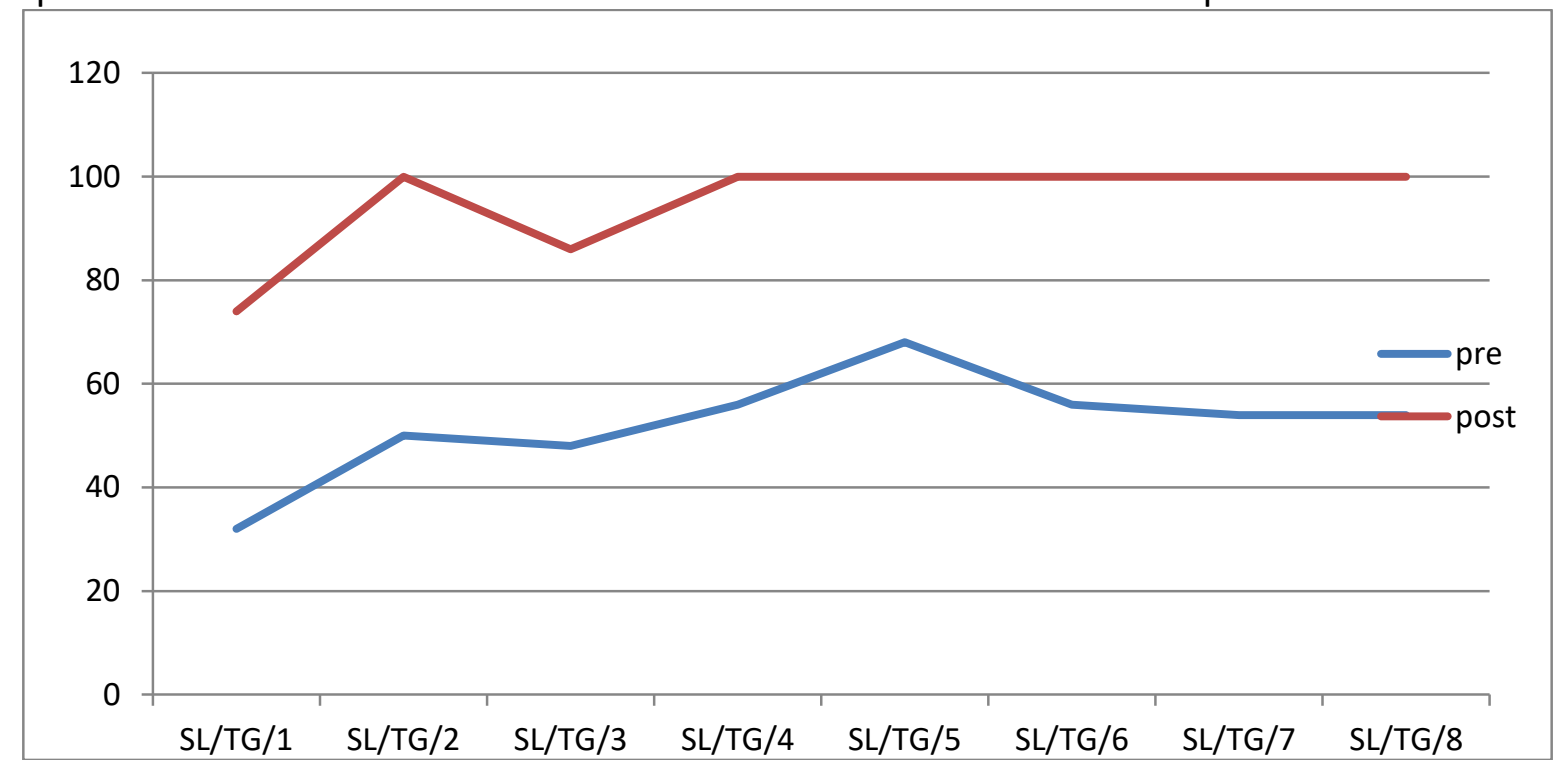

Graph Graph 2: Pre-test and Post-test scores for Slow Learners in Treatment Group

Table 4, Graph 1 and Graph 2 show scores by the slow learner in control and treatment group in both pre- and post-test. Pre-test scores for SL/CG/T/1 (72), SL/CG/T/2 (76), SL/CG/T/3 (76), $\mathrm{SL} / \mathrm{CG} / \mathrm{T} / 4$ (72), SL/CG/T/5 (80), SL/CG/T/6 (30), SL/CG/T/7 (16) and SL/CG/T/8 (12). Post-test scores for SL/CG/T/1 (78), SL/CG/T/2 (78), SL/CG/T/3 (80), SL/CG/T/4 (74), SL/CG/T/5 (86), $\mathrm{SL} / \mathrm{CG} / \mathrm{T} / 6$ (20), SL/CG/T/7 (16) and SL/CG/T/8 (18). Mean score for pre-tests is 54.2 and posttest mean is 56.2. Overall, mean differences for pre-test and post-test in control group is 2 .

In the control group, pre-test score for SL/TG/1 (32), SL/TG/2 (50), SL/TG/3 (48), SL/TG/4 (56), SL/TG/5 (68), SL/TG/6 (56), SL/TG/7 (54) and SL/TG/8 (54). Post-test scores for SL/TG/1(74), SL/TG/2 (100), SL/TG/3 (86), SL/TG/4 (100), SL/TG/5 (100), SL/TG/6 (100), SL/TG/7(100) and $\mathrm{SL} / \mathrm{TG} / 8$ (100). Mean score for pre-tests is 52.2 and post-test is 95.0 . Overall, mean differences for pre-test and post-test in treatment group is 42.8 . 
INTERNATIONAL JOURNAL OF ACADEMIC RESEARCH IN PROGRESSIVE EDUCATION AND DEVELOPMENT

Vol. 7, No. 3, July 2018, E-ISSN: 2226-6348 @ 2018 HRMARS

This result shows large mean differences in pre-test and post-test for the slow learners in both group of 40.8. By comparing the mean differences between students in the control group and treatment group, it was found that multimedia interactive, particularly using augmented reality technique help slow learners in their reading and writing skills.

\section{Discussion}

Results of the study provide evidence of the overall effectiveness of the module for improving the single-word reading skills of the treatment groups among slow learners students. Students who participated in the treatment group learn to read approximately 55 words (according to their abilities) over a range of three months period. The module instructional was incorporated empirically validated and engaging students with AR cards tasks. Given the success of participants in learning to read targeted words, result from the current study support AR as an adapted directinstruction reading activities.

This finding agreed with Mihandoost et al. (2011) that reading attitude and motivation in reading may lead to a major challenge to the self esteem or negative impact upon their general self development. The finding also agreed that multimedia-based helps learners in the classroom (Zhang, 2003; Schulz \& Dahale, 1999; Jandi, 2000). Therefore, school must play its parts in giving more reading experiences to students with special needs and to implement more opportunities to use multimedia materials in the classrooms.

\section{Conclusion}

The facts remains that students need to learn and access the computer more often. This study strongly found that students with special needs liked and admired the LitAR cards and they also found it awesome when the illustrations pops up into three dimension model. Therefore, teachers need to know and learn how to develop more high tech teaching aids in order to inspire their clients who are the students.

\section{Acknowledgement}

This work was supported by The Ministry of Higher Education, Universiti Pendidikan Sultan Idris (UPSI), the Research Management and Innovation Centre of UPSI and the Faculty of Education and Human Development, UPSI.

[Fundamental Research Grant Scheme: 2014-0112-106-012].

\section{Corresponding Author}

Assoc. Prof. Dr. Noor Aini Ahmad

Special Education Department

Universiti Pendidikan Sultan Idris

35900 Tanjong Malim

Perak, Malaysia

Email: noor.aini@fpm.upsi.edu.my 


\section{References}

Abosi, O. (2007). Educating Children with Learning Disabilities in Africa. Learning Disabilities Research \& Practice. 22(3), 196-201.

Bahadur, G.K. \& Boodun, S.S. (2013). Using powerpoint presentations as a tool for effective teaching and learning of water science for upper primary pupils in Mauritius. International Journal of Science, Mathematics and Technology Learning. 19(2), 65-78.

Denton, C. A. (2012). Response to intervention for reading difficulties in the primary grades: Some answers and lingering questions. Journal of Learning Disabilities. 45(3), 232-243.

Faye, K. (2013). Disproportionality and acting-out behaviors among African American children in special education. Journal of Acting-Out Behaviors Among African American. 30, 487-504.

Hargittai, E. \& Shafer, S. (2006). Differences in actual and perceivedonline skills: the role of gender. Southwestern Social Science Association. 87(2), 432-448.

Jandl, A.K.M. (2000). Diversified use of ICT in education. Campus-Wide Information Systems. 17(5), 161-166.

Korat, O. (2010). Reading electronic books as a support for vocabulary, story comprehension and word reading in kindergarten and first grade. Computers \& Education. 55, 24-31.

Lee Lay Wah. (2007). Development of multimedia learning resources for children with learning disabilities in an undergraduate special education technology course. MEDC. 1, 29-36

Lin, C.H., Liu, E. Z. F., Chen Y. L., Liou, P.Y., Chang, M., Wu, C.H. \& Yuan, S.M. (2013). Game-based remedial instruction in mastery learning for upper-primary school students. Educational Technology \& Society. 16 (2), 271-281.

Lo, J. J., Wang, H. M. \& Yeh, S. W. (2004). Effects of confidence scores and remedial instruction on prepositions learning in adaptive hypermedia. Computers \& Education. 42(1), 45-63.

Mayer, R.E. (2003). The promise of multimedia learning: using the same instructional design methods across different media. Learning and Instruction. 13, 125-139.

Mihandoost, Z., Habibah Elias, Sharifah Syed \& Rosnaini Mahmud. (2011). A comparison of the reading motivation and reading attitude of students with dyslexia and students without dyslexia in the elementary schools in Ilam, Iran. International Journal of Psychological Studies. 3(1), 17-27.

Mohammed Alzyoudi, Abed Alziz Sartawi \& Osha Almuhiri. (2014). The impact of video modelling on improving social skills in children with autism. British Journal of Special Education. 42(1), 54-68.

Nkansah, G.B. \& Unwin, T. (2010).The contribution of ICTs to the delivery of special educational needs in Ghana: practices and potential. Information Technology for Development. 16(3), 191-211.

Norhayati Abd Mukti \& Siew Pei Hwa. (2015). International forum of educational technology \& society malaysian perspective: designing interactive multimedia learning. Journal of Educational Technology \& Society. 7(4), 143-152.

Orelus, P. W. \& Hills, M. (2010). Rethinking literacy development of bilingual students with special needs: challenges, struggles and growth. International Journal of Special Education. 25(2), 156-177. 
INTERNATIONAL JOURNAL OF ACADEMIC RESEARCH IN PROGRESSIVE EDUCATION AND DEVELOPMENT

Vol. 7, No. 3, July 2018, E-ISSN: 2226-6348 @ 2018 HRMARS

Paneque, O.M. \& Rodriguez, D. (2009). Language use by bilingual special educators of english language learners with disabilities. International Journal Of Special Education. 24(3), 6369

Patton, B., Crosby, S., Houchins, D. \& Jolivette, K. (2010). The comparative effect of fluency instruction with and without a Comprehension strategy for elementary school students. International Journal Of Special Education. 25(2), 100-112.

Pérez, L. F. \& Beltrán, J.A. (2008). A Spanish intervention programme for students with special education needs: effects on intellectual capacity and academic achievement. European Journal of Special Needs Education. 23(2), 147-156.

Rasinski, T. (2006). Reading fluency instruction: moving beyond accuracy, automaticity and prosody. The Reading Teacher. 59(7), 704-706.

Schulz, K.C. \& Dahale, V. (1999). Multimedia modules for enhancing technical laboratory sessions. Campus-Wide Information Systems. 16(3), 81-95.

Seagers. N. \& Verhoeven, N. (2002). Multimedia support of early literacy learning. Computers \& Education. 39, 207-221.

Sella, F., Tressoldi, P., Lucangeli, D. \& Zorzi, M. (2016). Training numerical skills with the adaptive videogame The Number Race: A randomized controlled trial on preschoolers. Trends in Neuroscience and Education. 5(1), 20-29.

Shamir, A., Korat, O. \& Barbi, N. (2008). The effects of CD-ROM storybook reading on low SES kindergarteners' emergent literacy as a function of learning context. Computers \& Education. 51, 354-367.

Solis, M., Ciullo, S., Vaughn, S., Pyle, N., Hassaram, B. \& Leroux, A. (2012). Reading comprehension interventions for middle school students with learning disabilities: A synthesis of 30 years of research. Journal of Learning Disabilities. 45 (4), 327-340.

Stetter, M.E. \& Hughes, M.T. (2011). Computer assisted instruction to promote comprehension in students with learning disabilities. International journal of special education. 26(1), 88100.

Temple, C., Ogle, D., Crawford, A. \& Freppon, P. (2005). All Children Read: Teaching for Literacy in Diverse Classrooms. New York: Addison Wesley Longman.

Tse-Kian Neo \& Mai Neo. (2004). Classroom innovation: engaging students in interactive multimedia learning. Campus-Wide Information Systems. 21(3), 118-124.

Vandenberg, B. \& Emery, D. 2009. A longitudinal examination of the remediation of learning disabilities: IQ, age at diagnosis, school SES and voluntary transfer. International Journal of Special Education. 24(1), 45-52.

White R.B., Polly, D. \& Audette, R.H. (2012). A case analysis of an elementary school's implementation of response to intervention. Journal of Research in Childhood Education. 26(1), 73-90.

Zhang, E.Y. \& Loeb, L. (2013). Mobile Applications: Games that Transform Education. Dartmouth Computer Science Technical Report. 1-20. 